\title{
On the semiotic aspects of visual arts ${ }^{1}$
}

\section{Yurij Lekomtsev}

\begin{abstract}
Publication of a translation of an article by Yurij Lekomtsev, member of the Tartu-Moscow School with the author's comments and a short bionote.
\end{abstract}

Keywords: semiotics; artistic communication; aesthetic theory

$\$ 1$. The present article is written by a linguist, and it is written in close relation to issues in linguistics. First, the study of a semiotic object other than language expands the perspective of the linguist (this was already pointed out by F. de Saussure), preparing them for the transition from a descriptive point of view towards a theoretical one - in particular, it introduces them to other forms of messages than linear ones (two-dimensional, $n$-dimensional). Secondly, in natural languages themselves there are such emotional and aesthetic moments that can be understood better in their own domains.

$\$ 2$. By signs of a certain system $S$ we will understand a certain number of sensory perceptive and relatively uniform phenomena (явлений), which follow a set of spatio-temporal rules (i.e., a specific syntax) and let us sample (квантовать), or reduce to a limited number of elements, that flurry of experience (воздействия) which the outside world brings down on us².

Signs are the condensers and preservers of information about the outside world. Signs are the inevitable means of human communication with the outside world and others of their kind.

The human being is surrounded by systems of signs which are interrelated. Some of them are in successive subordination (creating a hierarchy). The most important group of sign systems are the sign systems of perception. Thus, for an

1 The Russian-language original version of this article appeared as Лекомцев Ю.К. 1965. О семиотическом аспекте изобразительного искусства. Труды по знаковым системам [Sign Systems Studies] 3: 130-145. The article was translated from Russian by Anna Slashcheva; the reference list and the bibliography were compiled by Silvi Salupere. The following footnotes are by the author of the text.

2 Cf. the passage of E. Schrödinger about the scope of our perception (Schrödinger 1956: 6). 
observer, a certain phenomenon (явление) (which can be described as a specific electromagnetic wavelength) is replaced by the feeling of colour ${ }^{3}$.

Natural languages and verbal speech are other examples of the sign system which "cater" to humans. By use of graphic materials, verbal language is transformed into written language. Artificial languages are built by means of simplification and specification of syntactic and semantic rules on the basis of written language. The system of the natural language is transferred into materials of different kinds: the language of flag signals, beating tam-tam drums, etc. Systems of greetings, rituals, play, systems of behaviour are close to sign systems.

$\$ 3$. From the formal point of view, a sign presents itself as a percept from the class of percepts, united by a set of rules of their combination which replace the class of denotata for the subject (interpreter of the sign) ${ }^{4}$.

The science of signs is divided into three parts: syntax, which studies the relations between signs; semantics, which studies the relations of signs to their denotata; and pragmatics, which studies the relation of the interpreter to signs. What is important for the classification of signs are the types of relations between the signs (syntactic rules), the types of relations between the class of denotata and the interpretant of the sign, and the type of relations of the interpreter to the sign (in particular, the goals and ways of using the systems). The type of sign is a function of several arguments.

Usually the following types of signs are distinguished (Peirce 1932: 135; Reichenbach 1947).

Sign as an image - icon. Its correlation with an object (class of denotata) bears a character of continuous or near continuous correspondence; for example, the drawing of a tree and a tree.

Sign - index. The correspondence between it and the object is not continuous but ambiguous, of a statistical character; for example, smoke is the index of fire ${ }^{5}$.

3 Cf. the passage from Helmholtz, for instance: "Unsere Empfindungen sind eben Wirkungen welche durch äussere Ursachen in unseren Organen hervorgebracht werden und wie eine solche Wirkung sich äußert, hängt natürlich ganz wesentlich von der Art des Apparatus ab, auf den gewirkt wird. Insofern die Qualität unserer Empfindung uns von der Eigentümlichkeit der äußerer Einwirkung, durch welche sie erregt sich, eine Nachricht gibt, kann sie als ein Zeichen derselben gelten, aber nicht als ein Abbild”. (Helmholtz 1921: 115). See also Gätschenberger 1920.

4 Cf. the definition of Ch. S. Peirce (1932: 135): "A sign, or representamen, is something which stands to somebody for something in some respect or capacity. It addresses somebody, that is, creates in the mind of that person an equivalent sign, or perhaps a more developed sign. That sign which it creates I call the interpretant of the first sign. The sign stands for something, its object".

5 This refers to the formal types of signs. 
Sign - symbol. Discrete character of correspondence ${ }^{6}$. In the logical language, the correspondence between the class of the denotata and symbol tends to mutual univocity.

$\$ 4$. The concept of sign is implicitly or explicitly connected to the opposition between I and non-I, i.e. it has an epistemological character. There is a concept which does not have an epistemological character - a concept of message which contains information. This concept can be used (apart from epistemology) to describe the causal relations in the world of things, or to describe communication between different parts of the neural system inside us.

Information theory operates by notions of sender and receiver, having coding and decoding devices for every message, which consists of signals and a channel by which the message is transmitted. Every sign can be viewed as a particular case of message, in which the notion of the sender of the message is replaced by the notion of the denotatum.

$\S 5$. Sign systems are differentiated by the way humans use them. Their ability to act as a means of communication is of big importance. From this point of view, verbal speech constitutes a communicative system, while signs of perception do not.

$\$ 6$. Let us build our argument on the basis of the expression (by expression we will mean a set of lines or spots, coloured or toned) which someone likes. The expression is divided into elements which may be grouped into the equivalent classes (straight lines, looped curves, non-looped curves, etc.) and hierarchical classes (for instance by the square size of spots). At the moment, the procedure of analysis is not interesting to us: it is just necessary to stress that the expression can be understood as a structure, elements of which are subject to a certain syntax ${ }^{7}$.

6 From the point of view of concrete sign systems, as mentioned in $₫ 2$, this example is a fact of syntax of the signs of perception, which is similar to the functions between the elements of verbal language; thus, for instance, Chinese $d e$ with a certain likelihood predicts the following noun. From the formal point of view, this is an index sign as well.

7 Syntax of the elements may be reconstructed only partially on the basis of a single expression. It can be reconstructed fully on the basis of the series of expressions of one author, one school, etc. (cf. the language syntax reconstructed on the basis of one phrase and on the basis of a larger text). As an illustration we can use the following idealized example: artist A and artist $\mathrm{B}$ created one picture (expression) each:

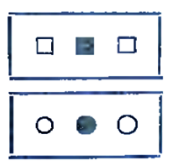

On the basis of these paintings one may say that A and B have the same syntax (horizontal 
The number of different elements of an expression which can be split up is called the variety of an expression. It seems that not all possible combinations of elements will be equally liked. The choice of the "beautiful" combinations is related to a certain delimitation of the possible combinations.

Aesthetic can be seen as the rules which limit the syntax of the elements within an expression.

An expression, usually constructed on the basis of aesthetic rules, not only pleases, but also tells something to the viewer, i.e. transmits some information. There are two types of information: outer, or representative, and inner, or emotional. The cases where an expression represents a human being, scenery, universe, speed, etc., are examples of representative information. An expression of sadness with shades of blue, or expression of intensity of emotions with red can serve as an example of emotional information.

It is interesting that the desire to interpret pure expressions is so strong in us that we even assign emotional and representative information to the undeliberate workings of nature. For instance, look at the structure of Armenian rocks:

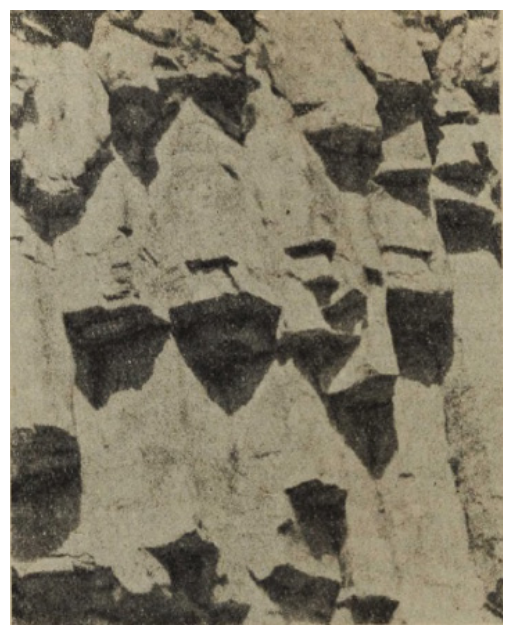

symmetry, linear arrangement of the elements). However, if we look at the following series of paintings of $A$ and $B$, we can see that the syntax of expressions of $A$ and $B$ is different:
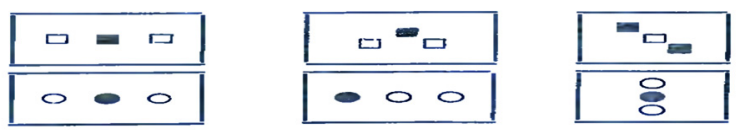

For A, the horizontal and diagonal symmetry is relevant, while the linear order is not; for B, the linear ordering of the elements in two axes is relevant, but symmetry is not (i.e. it is not the necessary rule of syntax). 
The emotional interpretation of this expression for us would be feelings of magnitude, despondency, etc. The representative interpretation would be stony faces of people across many ages.

$\$ 7$. The question about the nature of the aesthetic limitations is very complicated and not well developed. We imagine them as certain mathematical relations, such as the well-known golden ratio (cf. Ghyka 1927). We are most interested in the conception of the aesthetic forms (expressions) as economic and stable states from the point of view of the perception algorithm (cf. Arnheim 1954). The concept of the beautiful is also important as a certain correlation of complicity and easiness of the expression (Hogarth 1753; on the modern level cf. Birkhoff 1950: 320, 333).

$\$ 8$. In cases where an expression contains representative information, another aesthetic mode appears: here, the aesthetic is a function of the simplicity and economy of the image.

$\$ 9$. The issue of abstraction in art is close to the issues of the representative and emotional content, i.e. "abstract" expression can be representative, for instance, showing 'human in general, 'human solidarity', 'supersonic speed', or it can be nonrepresentative, emotional. Finally, an expression can be called abstract if it does not carry any concise information but has clearly expressed aesthetic moments.

$\$ 10$. The aforementioned artistic concepts can be described by means of general semiotics in the following way. The expression is built from a certain number of elements of perception, the compatibility of which are delimited (the syntactic aspect of the beautiful). This expression is an image-sign in relation to representative information.

In relation to emotional information, the expression is a certain type of message (for more about the concept of message see above).

For expressions with representative information the following should be added: since art is based on the language of perception, the perception of abstract (nonperceivable) objects is connected with a breaking of the continuous correlation, and the sign of the image changes into sign-symbol.

The message conveying emotional information remains the symbol sign which is only partly motivated ${ }^{8}$.

It is important to distinguish between emotional symbols and conceptual symbols when the elements of perception, for instance, colours, are as equivalents of elements of the verbal language (usually with an abstract meaning).

An example of the former is the fact that in Ancient Egypt the natural red colour of cheeks was perceived as something ominous, while cheeks coloured in green were considered beautiful.

8 On emotional information see in particular Hegel 1956: 116-117. 
An example of the latter is the colour symbolism in pre-Columbian America, where colours were connected with cardinal points: black and the north, white and the west, red and the east, blue and the south, and via that with other meanings. Black and red (i.e. darkness and light) served as a symbol of knowledge (see LeónPortilla 1967).

In cases of the sign-image and the message containing symbolic information, the semantic aspect of the beautiful arises regarding the choice of the most economical and original means of correspondence.

In the semiotic plan, the syntactic aspect of the aesthetic, intrinsic to the perceived forms of the outer world and expressions of art as well (see White 1951) can be compared to the concept of structure proposed by L. Wittgenstein, common to propositions and situations. ${ }^{9}$ Such phenomena can be conveniently called 'the foundation'.

Consequently, we can say that the aesthetic foundation exists in expressions made from any substance (coloured, sound, taste, tactile). It must be said that the concept of 'beautiful' in the natural languages, and, probably, aesthetic limitations of syntax may be used not only in systems of perception, but also with regards to other semiotic systems: see, for instance, the idea of the beautiful game, say, a football match.

Formal logic, which is a sort of limitation of natural language, may include aesthetic limitations - the shorter derivation of theorems from axioms may be considered beautiful.

$\$ 11$. A perceived substance is sampled from three points of view, including things relevant or aesthetically irrelevant, emotional and imaginary (cf commutation principle in linguistics).

$\$ 12$. The set of aesthetic limitations changes depending on ethnicity and time ${ }^{10}$.

$\$ 13$. The aesthetic limitations of syntax and information which is contained in an expression (especially an emotional one) may hardly be distinguished in the work of art. In this regard, it is important to study nature expressions (textures and drawings on stones, forms of plants, etc.), which do not contain deliberate information, and reactions of the target population (their opinions)

9 Cf. Wittgenstein 1922: 2.161: "In the picture and the pictured there must be something identical in order that the one can be a picture of the other at all."

10 In this respect it is interesting how W. Hogarth, who seeked for universal laws of beauty far from aesthetic canons, estimated the "other" aesthetic canons: "[...] the deities of barbarous and gothic nations never had, nor have to this day, any of these elegant forms belonging to them. How absolutely void of these turns are the pagods of China." (Hogarth, William 1753. The Analysis of Beauty. London, xix, available at https://www.gutenberg.org/files/51459/51459h/51459-h.htm, S. S.) 
to such expressions. It seems that the study of reactions of the audience on the expressions based on mathematical formulae (for instance, the images of nonlinear expressions) would be even more important.

$\$ 14$. In general, the work of art should be viewed as a specific message in some communication. The communicative situation includes a creator of the work of art and its audience who share codes or aesthetic models in their consciousness, similar in structure, and, finally, the environment, taken in its widest meaning: the world of nature, human society, cultural values, etc.

The role of the viewer is not, of course, reduced to simple mechanical decoding (or to the sum of the processes of mechanical decoding); the perception of the work of art creates a general reaction, makes some people close, others distant, serves as a conductor of influence from one to others, etc.

The creator of the work of art is always under constant influence of society (i.e., the audience). This influence is more mediated before the work of art is created and becomes part of the communicative situation after its creation. And, finally, the environment influences both the creator and the audience, providing common aesthetic models, content and the need to communicate.

But if all non-aesthetic (for instance, verbal) forms of influence are excluded, the scheme of the situations become simpler.

\section{Scheme of artistic communication}

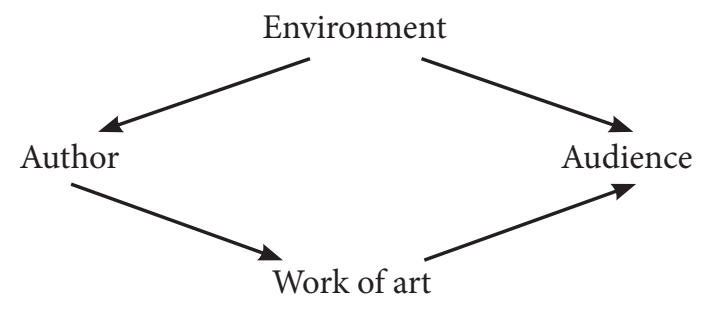

\section{$\$ 15$. Conclusion.}

We have expressed only the most general ideas about the semiotic approach to arts. Experimental research is needed for further development of the theoretical concepts.

In general, in our opinion, general aesthetic theory and psychological experimental research on perception and art creation, together with the history of art, are the two levels of abstraction of one science, between which "feedback" should be provided. ${ }^{11}$

11 We would like to express our deep gratitude to M. I. Lekomtseva, with whom we discussed many ideas of the work and Yu. V. Knorozov for a very valuable consultation. 


\section{References}

Arnheim, Rudolf 1954. Art and Visual Perception: A Psychology of the Creative Eye. Berkeley, Los Angeles: University of California Press.

Birkhoff, George David 1950. Collected Mathematical Papers. Vol. 3. New York: Dover Publications.

Gätschenberger, Richard 1920. Symbola. Anfangsgründe einer Erkenntnistheorie. Karlsruhe: G. Braun Kommissionverlag.

Ghyka, Matila 1927. Esthétique des proportions dans la nature et dans les arts. [In Russian translation.] Moscow 1933.

Hegel, Georg Wilhelm Friedrich 1956[1830]. Entsiklopediya filosoficheskih nauk 3. Filosofiya duha. Moscow: Izdatel'stvo politicheskoj literatury. [Гегель, Георг Вильгельм Фридрих. Энииклопедия философских наук. Часть 3. Философия духа/Enzyklopädie der philosophischen Wissenschaften im Grundrisse. Teil 3. Die Philosophie des Geistes. Москва: Издательство политической литературы.]

Helmholtz, Hermann von 1921. Schriften zur Erkenntnistheorie. Berlin: Springer.

León-Portilla, Miguel 1967. Aztec Thought and Culture: A Study of the Ancient Nahuatl Mind. (Davis, Jack Emory, trans.) Norman: University of Oklahoma Press.

Peirce, Charles Sanders 1932. The Collected Papers of Charles Sanders Peirce. Vol. 2: Elements of Logic. (Hartshorne, Charles; Weiss, Paul, eds.) Cambridge: Harvard University Press.

Reichenbach, Hans 1947. Elements of Symbolic Logic. New York: The Free Press.

Schrödinger, Erwin 1956. What is Life? and Other Scientific Essays. Garden City: Doubleday.

Wittgenstein, Ludwig 1922[1921]. Tractatus Logico-Philosophicus. New York: Harcourt Brace \& Company.

Whyte, Lancelot Law (ed.) 1951. Aspects of Form. A Symposium on Form in Nature and Art. London: Lund Humphries.

\section{О семиотическом аспекте изобразительного искусства}

Перевод на английский язык статьи участника Тартуско-московской школы Юрия Константиновича Лекомцева с комментариями и краткой биографической справкой.

\section{Kujutava kunsti semiootilisest aspektist}

Tartu-Moskva koolkonna liikme Juri Lekomtsevi artikli tõlge inglise keelde koos kommentaaride ja lühikese tutvustusega.

Yurij Konstantinovich Lekomtsev, Doctor of Philology (1929-1984) was a linguist who worked at the Institute of Oriental Studies of the Academy of Sciences of the USSR. His main research interests included structural linguistics and semiotics, Indology and the languages of Southeast Asia. He devoted his life to creating a formal theory of language, developing glossematic ideas with the use of mathematics. His father was a well-known painter, and Yurij was gifted not only in painting and poetry, but also in the theory of art. The article published here in English translation was an attempt to build a formal model for the description of the language of art. 
Lekomtsev was a steady participant in the Semiotics Summer Schools held at Kääriku, concerning which Vyacheslav Ivanov recalls his presentations about Santal mythology in which he competed with Uku Masing, the famous Estonian author and cultural and religious scholar, in the scope and depth of his knowledge (Ivanov 1987: 145).

In Lekomtsev's obituary, Juri Lotman wrote, "I was lucky enough to meet very courageous people in my life, and able to enjoy communicating with brilliantly gifted people. But even in this circle Yurij Konstantinovich Lekomtsev was blessed with strength of mind and brilliant talent. There was always something childlike about his face: even when the signs of the painful disease had already clearly been drawn on it, it exuded that exclusive charm which will never be forgotten by anybody who was lucky to have met him" (Lotman 1987: 147).

\section{References}

Ivanov, Vyacheslav 1987. Pamyati Yuriya Konstantinovicha Lekomtseva. Sign Systems Studies 20: 141-145. [Иванов, Вяч. Вс. 1987. Памяти Юрия Константиновича Лекомцева. /In memory of Yurij Konstantinovich Lekomtsev. Труды по знаковым системам 20: 141-145.].

Lotman, Juri 1987. In memoriam. Sign Systems Studies 20: 146-147. [Лотман, Ю. M. 1987. In memoriam. Труды по знаковым системам 20: 146-147.]

\section{Short bibliography of works of Yurij Lekomtsev}

Lekomtsev, Yurij 1962. K voprosu o sistemnosti glagolov rechi v anglijskom yazke. In: Problemy strukturnoj lingvistiki. Moscow: Press of the Academy of Sciences of the USSR, 190-197. [Лекомцев Ю. К. 1962. К вопросу о системности глаголов речи в английском языке. In: Проблемы структурной тингвистики. Москва: Изд-во АН СССР, 190-197.]

Lekomtsev, Yurij 1969. Glossematicheskaya teoriya lingvisticheskih oppozitsij i teoriya razlicheniya v semantike i deskriptivnoj semiotike. Sign Systems Studies 4: 434-459. [Лекомцев Ю. К. 1969. Глоссематическая теория лингвистических оппозиций и теория различения в семантике и дескриптивной семиотике./Glossematic theory of linguistic oppositions and differentiation theory in semantics and descriptive semiotics. Труды по знаковым системам 4: 434-459.]

Lekomtsev, Yurij 1973. Psihicheskaya situatsiya, predlozhenie i semanticheskij priznak. Sign Systems Studies 6: 444-463. [Лекомцев Ю. К. 1973. Психическая ситуация, предложение и семантический признак./Psychical situation, sentence and semantic feature. Tруды по знаковым системам 6: 444-463.]

Lekomtsev, Yurij 1975. Ob algebraicheskom podhode k sintaksisu tsvetov v zhivopisi. Sign Systems Studies 7: 193-205. [Лекомцев Ю. К. 1975. Об алгебраическом подходе к синтаксису цветов в живописи./On the algebraic approach to the syntax of colours in painting. Труды по знаковым системам 7: 193-205.]

Lekomtsev, Yurij 1979. Protsess abstragirovaniya v izobrazitel'nom iskusstve i semiotika. Sign Systems Studies 9: 120-142. [Лекомцев Ю. К. 1979. Процесс абстрагирования в изобразительном искусстве и семиотика./The process of abstractiona in fine arts and semiotics. Труды по знаковым системам 9: 120-142.]

Lekomtsev, Yurij 1982.. In: Allgemeine Sprachwissenschaft, Sprachtypologie und Textlinguistik. Festschrift für Peter Hartmann. Tübingen: G. Narr, 187-196.

Lekomtsev, Yurij 1983. Vvedenie v formal'nyj yazyk lingvistiki. Moscow: Nauka. [Лекомцев Ю. К. 1983. Введение в формальный язык лингвистики/Introduction to Formal Language of Linguistics. Москва: Наука.] 